\title{
Accounting Disclosure, Governance Standards and Innovation Activities in Emerging Markets
}

\author{
Zhenxiang Chen \\ Wuhan Yangtze Business University \\ 3, Huangjiawu West Road, Hongshan District, Wuhan, Hubei 430065, China \\ E-mail: 541922306@qq.com \\ Ming Li (Corresponding author) \\ Wuhan Yangtze Business University \\ 3, Huangjiawu West Road, Hongshan District, Wuhan, Hubei 430065, China \\ E-mail: 36010526@qq.com
}

\begin{abstract}
Liang Song
Michigan Technological University

1400 Townsend Drive, Houghton, MI 49931, United States

E-mail: liangs@mtu.edu

Yanan Xing

Huaxin Trust Co., Ltd.

34 Dagong St, Xigang, Dalian, Liaoning, China, 116011

E-mail: 82272933@qq.com
\end{abstract}

\section{Zhaoguo Zhang}

Huazhong University of Science and Technology

1037 Luoyu Road, Wuhan, Hubei 430065, China

E-mail: xuehai0225@126.com 
Received: April 13, 2014 Accepted: Sep. 24, $2014 \quad$ Published: December 1, 2014

doi:10.5296/ajfa.v6i2.6133 URL: http://dx.doi.org/10.5296/ajfa.v6i2.6133

\begin{abstract}
We investigate how investor protection resulted from country-level and firm-level governance standards influence the relationship between market disciplines resulted from firm-level accounting disclosure and innovation activities. Employing a sample across 14 emerging markets, evidence confirms that the effects of firm-level accounting disclosure on innovation activities are more important in a country with weaker governance standards and for firm with poor corporate governance. The results suggest that market disciplines can substitute for investor protection.
\end{abstract}

Keywords: Accounting Disclosure, Governance Standards, Emerging Markets, Innovation Activities 


\section{Introduction}

The existing literature shows that innovation contributes to countries' economic growth (Aghion and Howitt, 2006) and firms are trying to promote innovation (Hoskisson et al., 2002). Much of the extant research is based on the managerial conflicts (Jensen and Meckling, 1976; Holmstrom, 1989). The existing empirical studies find that innovation is determined by several corporate factors (Francis et al., 2012a; O'Connor and Rafferty, 2012; Aghion, Van Reenen, and Zingales, 2013). While most of the conclusion has been from U.S. firms, recent research has also investigated emerging economies (Chen et. al., 2011; Francis et al., 2012b; Gibson, 2003; Hasan and Song, 2014a; Klapper and Love, 2004). Our research further analyzes innovation in emerging countries by considering the impact of country-level and firm-level governance standards on the relationship between accounting disclosure and innovation, as measured by R\&D.

According to the agency theory, managers are trying to maximize their own interest by conducting less investment to research and development and investing more in safe projects. Strong governance mechanisms such as investor protection and market discipline should reduce such agency problems (See O’Connor and Rafferty, 2012)

Although the literature has addressed the effects of market disciplines resulted from accounting disclosure on innovation activities, there is little evidence of whether the effects of market disciplines are more important in a country with weaker investor protection and for firms with poor corporate governance. One hypothesis is that if governance is weak, then accounting disclosure is less credible and market disciplines are less effective (Hasan and Song, 2014; Hasan et al., 2014b). An alternative hypothesis is that if the firm is located in countries with weak legal systems and investor protections and has poor corporate governance, shareholders and owners would welcome even small improvements in market disciplines relative to other firms (Klapper and Love, 2004).

To test our hypotheses, our firm-level accounting disclosure and corporate governance data is obtained from the survey data by Credit Lyonnais Securities Asia. We use the three country-level governance measures such as judicial efficiency, legality, and shareholder rights from La Porta et al. (1998) and the International Country Risk Guide (2000). We obtain our dependent variable from Worldscope, and define R\&D as the ratio of a firm's $R \& D$ expenditures to sales. We also control for the logarithm of firm assets, total liability, accounting earnings, GDP growth, GDP per capita. Our sample period is between 2000 and 2005. Our final sample includes 807 observations in fourteen emerging markets.

Empirically, we use R\&D as our innovation measure. The key independent variables are the interaction terms between firm-level accounting disclosure and governance variables. Specifically, we estimate the following equation:

Company-R\&D $=\alpha+\beta 1$ Accounting-Disclosure $+\beta 2$ Governance Variables $+\beta 3$ Accounting-Disclosure * Governance Variables $+\beta 4$ Control variables + Industry effects + Year effects $+\varepsilon$

Across 14 emerging markets, evidence confirms that the effects of firm-level accounting 
disclosure on innovation activities are more important in a country with weaker governance standards and for firms with poor corporate governance. The results suggest that market disciplines resulted from firm-level accounting disclosure can substitute for investor protection resulted from country-level and firm-level governance standards.

Our analysis extends the existing research by examining how investor protection resulted from country-level and firm-level governance standards influence the relationship between market disciplines resulted from firm-level accounting disclosure and innovation activities. Compared with Hasan et al., (2014a), this paper discomposes the overall firm-level corporate governance into two components such as accounting disclosure and non-disclosure governance and examines the individual and interaction effects of these two components on firms' innovation activities. In the next section, we describe the data. Section 3 presents results. Section 4 provides conclusions.

\section{Variable Definition, Sample, and Descriptive Statistics}

In this subsection, we present the variable definition, the sample construction and the descriptive statistics. Our firm-level accounting disclosure and corporate governance data is from the survey data conducted by Credit Lyonnais Securities Asia. The variable Accounting-Disclosure measures the firms' accounting disclosure level such as whether the firms have disclosed their ROA in the previous years. The variable Firm-Governance captures non-disclosure governance level such as the board structure of the firms. We use the three country-level governance measures such as judicial efficiency, legality, and shareholder rights from La Porta et al. (1998) and the International Country Risk Guide (2000). We obtain our dependent variable from Worldscope, and define $R \& D$ as the ratio of a firm's $R \& D$ expenditures to sales. We also include the logarithm of firm assets, total liability, accounting earnings, GDP growth, GDP per capita. Our sample period is between 2000 and 2005. Our final sample includes 807 observations in fourteen emerging markets. We present summary statistics in Table 1.

As shown in Table 1, the mean value of the variable Accounting-Disclosure is equal to 59.01 and its standard deviation equals 21.32. The mean value of the variable Firm-Governance is equal to 58.02 and its standard deviation equals 22.24 . The mean value of the variable Log-GDP-Per-Capita is equal to 8.21 and its standard deviation equals 1.22 . The mean value of the variable $L o g-G D P$-Growth is equal to 1.61 and its standard deviation equals 0.32 . The mean value of the variable $\log$-Assets is equal to 14.11 and its standard deviation equals 1.41. The mean value of the variable Total-Liability is equal to 22.43 and its standard deviation equals 19.53. The mean value of the variable Accounting-Earnings is equal to 14.91 and its standard deviation equals 23.61. The mean value of the variable Company- $R \& D$ is equal to 2.71 and its standard deviation equals 1.22 . 
Table 1. Summary Statistics

\begin{tabular}{|l|c|c|c|c|c|}
\hline & Mean & Standard & $10^{\text {th }}$ & $50^{\text {th }}$ & $90^{\text {th }}$ \\
\hline & & deviation & Percentile & Percentile & Percentile \\
\hline Accounting-Disclosure & 59.01 & 21.32 & 20 & 50 & 90 \\
\hline Firm-Governance & 58.02 & 22.24 & 30 & 50 & 80 \\
\hline Log-GDP-Per-Capita & 8.21 & 1.22 & 6.62 & 8.21 & 10.02 \\
\hline Log-GDP-Growth & 1.61 & 0.32 & 1.20 & 1.61 & 2.02 \\
\hline Log-Assets & 14.11 & 1.41 & 12.44 & 14.11 & 16.01 \\
\hline Total-Liability (\%) & 22.43 & 19.53 & 0.30 & 19.21 & 49.42 \\
\hline Accounting-Earnings (\%) & 14.91 & 23.61 & 2.27 & 10.06 & 29.34 \\
\hline Company-R\&D (\%) & 2.71 & 1.22 & 1.50 & 2.51 & 3.58 \\
\hline
\end{tabular}

The table reports summary statistics. Our firm-level accounting disclosure and corporate governance data is from the survey data by Credit Lyonnais Securities Asia. We obtain our dependent variable from Worldscope, and define $R \& D$ as the ratio of a firm's $R \& D$ expenditures to sales. We also control for the logarithm of firm assets, total liability, accounting earnings, GDP growth, GDP per capita. Our sample period is between 2000 and 2005. Our final sample includes 807 observations in fourteen emerging markets.

\section{Methods and Results}

The summary statistics presented in the previous section show significant differences in innovation activities across emerging markets. We next conduct a more formal investigation, and employ the multivariate analysis to examine how investor protection resulted from country-level and firm-level governance standards influence the relationship between market disciplines resulted from firm-level accounting disclosure and innovation activities.

The existing literature has shown the effects of accounting disclosure in the emerging markets. For example, Hasan and Song (2014) present the evidence that banks provide better loan contracting terms to firms with better disclosure standards. They also find that the influence of accounting disclosure on the loan contracts is more significant for firms with superior governance environment. Hasan et al., (2014b) present the evidence that borrowers' better disclosure standards have a significant impact on bank loan syndicates. They also find that the influence of accounting disclosure on the loan syndicates is more significant for firms with superior governance environment. Hasan et al., (2014a) use a cross-section sample to present the evidence that firm-level corporate governance and country-level governance both have a significant effect on innovation activities.

Although the literature has addressed the effects of market disciplines resulted from accounting disclosure on innovation activities, there is little evidence of whether the effects 


\section{Macrothink Mnstitutem}

of market disciplines are more important in a country with weaker investor protection and for firms with poor corporate governance. One hypothesis is that if governance is weak, then accounting disclosure is less credible and market disciplines are less effective (Hasan and Song, 2014; Hasan et al., 2014b). An alternative hypothesis is that if the firm is located in countries with weak legal systems and investor protections and has poor corporate governance, shareholders and owners would welcome even small improvements in market disciplines relative to other firms (Klapper and Love, 2004).

We use R\&D as our innovation measure. The key independent variables are the interaction terms between firm-level accounting disclosure and governance variables. Specifically, we estimate the following equation:

Company-R\&D $=\alpha+\beta 1$ Accounting-Disclosure $+\beta 2$ Judicial-Efficiency $+\beta 3$ Accounting-Disclosure * Judicial-Efficiency $+\beta 4$ Control variables + Industry effects + Year effects $+\varepsilon$

Table 2. Regression with Investor Protection Measured by Judicial-Efficiency

\begin{tabular}{|l|c|c|}
\hline & \multicolumn{2}{|c|}{ Company-R\&D } \\
\hline & $(1)$ & $(2)$ \\
\hline Accounting-Disclosure & $0.0036^{* * *}$ & $0.0035^{* * *}$ \\
\hline & $(5.526)$ & $(5.672)$ \\
\hline Judicial-Efficiency & $0.0182^{* * *}$ & $0.0180^{* * *}$ \\
\hline & $(4.858)$ & $(4.973)$ \\
\hline Accounting-Disclosure * Judicial-Efficiency & $-0.0004 * * *$ & $-0.0005^{* * *}$ \\
\hline & $(-4.632)$ & $(-4.462)$ \\
\hline Log-Assets & & $0.2151^{* * *}$ \\
\hline & & $(5.345)$ \\
\hline Total-Liability & & 0.0052 \\
\hline & & $(0.341)$ \\
\hline Accounting-Earnings & & 0.0050 \\
\hline & & $(0.342)$ \\
\hline Control For & & \\
\hline Firm-Governance & Yes & Yes \\
\hline Log-GDP-Per-Capita & Yes & Yes \\
\hline Log-GDP-Growth & Yes & Yes \\
\hline Industry Effect & Yes & Yes \\
\hline Year Effect & Yes & Yes \\
\hline Observations & 807 & 641 \\
\hline Adjusted R-squared & 0.425 & 0.526 \\
\hline
\end{tabular}

The table reports coefficients and t-statistics. Significance at the $10 \%, 5 \%$ and $1 \%$ levels is indicated by $*, * *$, and $* * *$, respectively. In calculating standard errors, we cluster by firm. Our firm-level accounting disclosure and corporate governance data is from the survey data by Credit Lyonnais Securities Asia. We use the three country-level governance measures such as 
judicial efficiency, legality, and shareholder rights from La Porta et al. (1998) and the International Country Risk Guide (2000). We obtain our dependent variable from Worldscope, and define $R \& D$ as the ratio of a firm's R\&D expenditures to sales. We also control for the logarithm of firm assets, total liability, accounting earnings, GDP growth, GDP per capita. Our sample period is between 2000 and 2005. Our final sample includes 807 observations in fourteen emerging markets.

As shown in Table 2, the coefficients of the interaction terms between accounting disclosure and judicial efficiency are always statistically significant at $1 \%$ level. Specifically, the coefficient of the variable Accounting-Disclosure is equal to 0.0036 . The coefficient of the variable Judicial-Efficiency is equal to 0.0182 . The coefficient of the variable Accounting-Disclosure * Judicial-Efficiency is equal to -0.0004 . This finding indicates that the relation between accounting disclosure and $R \& D$ is stronger in countries with poor investor protection. When we include firm characteristics, the conclusion does not change. Specifically, the coefficient of the variable Accounting-Disclosure is equal to 0.0035 . The coefficient of the variable Judicial-Efficiency is equal to 0.0180 . The coefficient of the variable Accounting-Disclosure * Judicial-Efficiency is equal to -0.0005 . The coefficient of the variable Log-Assets is equal to 0.2151 .

Table 3. Regression with Investor Protection Measured by Country-Legality

\begin{tabular}{|l|c|c|}
\hline & \multicolumn{2}{|c|}{ Company-R\&D } \\
\hline & $(1)$ & $(2)$ \\
\hline Accounting-Disclosure & $0.0041^{* * *}$ & $0.0042^{* * *}$ \\
\hline Country-Legality & $(4.647)$ & $(3.746)$ \\
\hline & $0.0381^{* * *}$ & $0.0380^{* * *}$ \\
\hline Accounting-Disclosure * Country-Legality & $(4.573)$ & $(4.489)$ \\
\hline & $-0.0002^{* * *}$ & $-0.0002^{* * *}$ \\
\hline Log-Assets & $(-3.980)$ & $(-3.893)$ \\
\hline & & $0.2154 * *$ \\
\hline Total-Liability & & $(5.256)$ \\
\hline & & 0.0050 \\
\hline Accounting-Earnings & & $(0.301)$ \\
\hline & & 0.0052 \\
\hline Control For & & $(0.302)$ \\
\hline Firm-Governance & & \\
\hline Log-GDP-Per-Capita & Yes & Yes \\
\hline Log-GDP-Growth & Yes & Yes \\
\hline Industry Effect & Yes & Yes \\
\hline Year Effect & Yes & Yes \\
\hline Observations & Yes & Yes \\
\hline Adjusted R-squared & 807 & 641 \\
\hline
\end{tabular}

The table reports coefficients and t-statistics. Significance at the $10 \%, 5 \%$ and $1 \%$ levels is indicated by $*, * *$, and $* * *$, respectively. In calculating standard errors, we cluster by firm. Our firm-level 


\section{Macrothink}

Asian Journal of Finance \& Accounting

ISSN 1946-052X

2014, Vol. 6, No. 2

accounting disclosure and corporate governance data is from the survey data by Credit Lyonnais Securities Asia. We use the three country-level governance measures such as judicial efficiency, legality, and shareholder rights from La Porta et al. (1998) and the International Country Risk Guide (2000). We obtain our dependent variable from Worldscope, and define $R \& D$ as the ratio of a firm's R\&D expenditures to sales. We also control for the logarithm of firm assets, total liability, accounting earnings, GDP growth, GDP per capita. Our sample period is between 2000 and 2005. Our final sample includes 807 observations in fourteen emerging markets.

In table 3, we estimate the following equation:

Company-R\&D $=\alpha+\beta 1$ Accounting-Disclosure $+\beta 2$ Judicial-Efficiency $+\beta 3$ Accounting-Disclosure * Judicial-Efficiency $+\beta 4$ Control variables + Industry effects + Year effects $+\varepsilon$

As shown in Table 3, the coefficients of the interaction terms between accounting disclosure and legality are always statistically significant at $1 \%$ level. Specifically, the coefficient of the variable Accounting-Disclosure is equal to 0.0041 . The coefficient of the variable Country-Legality is equal to 0.0381 . The coefficient of the variable Accounting-Disclosure * Country-Legality is equal to -0.0002 . This finding indicates that the relation between accounting disclosure and $R \& D$ is stronger in countries with poor investor protection. When we include firm characteristics, the conclusion does not change. Specifically, the coefficient of the variable Accounting-Disclosure is equal to 0.0042. The coefficient of the variable Country-Legality is equal to 0.0380 . The coefficient of the variable Accounting-Disclosure * Country-Legality is equal to -0.0002 . The coefficient of the variable Log-Assets is equal to 0.2154 . 
Table 4. Regression with Investor Protection Measured by Shareholder-Rights

\begin{tabular}{|l|c|c|}
\hline & \multicolumn{2}{|c|}{ Company-R\&D } \\
\hline & $(1)$ & $(2)$ \\
\hline Accounting-Disclosure & $0.0043 * * *$ & $0.0040 * * *$ \\
\hline Shareholder-Rights & $(4.778)$ & $(4.457)$ \\
\hline & $0.0351^{* * *}$ & $0.0360 * * *$ \\
\hline Accounting-Disclosure * Shareholder-Rights & $(3.893)$ & $(4.782)$ \\
\hline & $-0.0011 * * *$ & $-0.0010^{* * *}$ \\
\hline Log-Assets & $(-4.987)$ & $(-4.815)$ \\
\hline & & $0.2143 * * *$ \\
\hline Total-Liability & & $(5.256)$ \\
\hline & & 0.0049 \\
\hline Accounting-Earnings & & $(0.300)$ \\
\hline & & 0.0055 \\
\hline Control For & & $(0.301)$ \\
\hline Firm-Governance & & \\
\hline Log-GDP-Per-Capita & Yes & Yes \\
\hline Log-GDP-Growth & Yes & Yes \\
\hline Industry Effect & Yes & Yes \\
\hline Year Effect & Yes & Yes \\
\hline Observations & Yes & Yes \\
\hline Adjusted R-squared & 807 & 641 \\
\hline & 0.441 & 0.519 \\
\hline
\end{tabular}

The table reports coefficients and t-statistics. Significance at the $10 \%, 5 \%$ and $1 \%$ levels is indicated by $*, * *$, and $* * *$, respectively. In calculating standard errors, we cluster by firm. Our firm-level accounting disclosure and corporate governance data is from the survey data by Credit Lyonnais Securities Asia. We use the three country-level governance measures such as judicial efficiency, legality, and shareholder rights from La Porta et al. (1998) and the International Country Risk Guide (2000). We obtain our dependent variable from Worldscope, and define $R \& D$ as the ratio of a firm's $R \& D$ expenditures to sales. We also control for the logarithm of firm assets, total liability, accounting earnings, GDP growth, GDP per capita. Our sample period is between 2000 and 2005. Our final sample includes 807 observations in fourteen emerging markets.

In table 4, we estimate the following equation:

Company-R\&D $=\alpha+\beta 1$ Accounting-Disclosure $+\beta 2$ Shareholder-Rights $+\beta 3$ Accounting-Disclosure $*$ Shareholder-Rights $+\beta 4$ Control variables + Industry effects + Year effects $+\varepsilon$

As shown in Table 4, the coefficients of the interaction terms between accounting disclosure and shareholder rights are always statistically significant at $1 \%$ level. Specifically, the coefficient of the variable Accounting-Disclosure is equal to 0.0043 . The coefficient of the 
variable Shareholder-Rights is equal to 0.0351. The coefficient of the variable Accounting-Disclosure * Shareholder-Rights is equal to -0.0011 . This finding indicates that the relation between accounting disclosure and $\mathrm{R} \& \mathrm{D}$ is stronger in countries with poor investor protection. When we include firm characteristics, the conclusion does not change. Specifically, the coefficient of the variable Accounting-Disclosure is equal to 0.0040. The coefficient of the variable Shareholder-Rights is equal to 0.0360 . The coefficient of the variable Accounting-Disclosure * Shareholder-Rights is equal to -0.0010 . The coefficient of the variable Log-Assets is equal to 0.2143 .

Table 5. Regression with Investor Protection Measured by Firm-Governance

\begin{tabular}{|l|c|c|}
\hline & \multicolumn{2}{|c|}{ Company-R\&D } \\
\hline & $(1)$ & $(2)$ \\
\hline Accounting-Disclosure & $0.0053^{* * *}$ & $0.0052^{* * *}$ \\
\hline Firm-Governance & $(4.799)$ & $(4.490)$ \\
\hline & $0.0050^{* * *}$ & $0.0068^{* * *}$ \\
\hline Accounting-Disclosure * Firm-Governance & $(3.898)$ & $(4.789)$ \\
\hline & $-0.0002^{* * *}$ & $-0.0002 * * *$ \\
\hline Log-Assets & $(-4.944)$ & $(-4.899)$ \\
\hline & & $0.2112^{* * *}$ \\
\hline Total-Liability & & $(5.222)$ \\
\hline & & 0.0044 \\
\hline Accounting-Earnings & & $(0.255)$ \\
\hline & & 0.0052 \\
\hline Control For & & $(0.300)$ \\
\hline Country-Legality & & \\
\hline Log-GDP-Per-Capita & Yes & Yes \\
\hline Log-GDP-Growth & Yes & Yes \\
\hline Industry Effect & Yes & Yes \\
\hline Year Effect & Yes & Yes \\
\hline Observations & Yes & Yes \\
\hline Adjusted R-squared & 807 & 641 \\
\hline
\end{tabular}

The table reports coefficients and t-statistics. Significance at the $10 \%, 5 \%$ and $1 \%$ levels is indicated by $*, * *$, and $* * *$, respectively. In calculating standard errors, we cluster by firm. Our firm-level accounting disclosure and corporate governance data is from the survey data by Credit Lyonnais Securities Asia. We use the three country-level governance measures such as judicial efficiency, legality, and shareholder rights from La Porta et al. (1998) and the International Country Risk Guide (2000). We obtain our dependent variable from Worldscope, and define $R \& D$ as the ratio of a firm's R\&D expenditures to sales. We also control for the logarithm of firm assets, total liability, accounting earnings, GDP growth, GDP per capita. Our sample period is between 2000 and 2005. Our final sample includes 807 observations in fourteen emerging markets. 
In table 5, we estimate the following equation:

Company-R\&D $=\alpha+\beta 1$ Accounting-Disclosure $+\beta 2$ Firm-Governance $+\beta 3$ Accounting-Disclosure * Firm-Governance $+\beta 4$ Control variables + Industry effects + Year effects $+\varepsilon$

As shown in Table 5, the coefficients of the interaction terms between accounting disclosure and firm-level governance are always statistically significant at $1 \%$ level. Specifically, the coefficient of the variable Accounting-Disclosure is equal to 0.0053 . The coefficient of the variable Firm-Governance is equal to 0.0050 . The coefficient of the variable Accounting-Disclosure * Firm-Governance is equal to -0.0002 . This finding indicates that the relation between accounting disclosure and $R \& D$ is stronger for firms with poor corporate governance. When we include firm characteristics, the conclusion does not change. Specifically, the coefficient of the variable Accounting-Disclosure is equal to 0.0052. The coefficient of the variable Firm-Governance is equal to 0.0068 . The coefficient of the variable Accounting-Disclosure * Firm-Governance is equal to -0.0002 . The coefficient of the variable Log-Assets is equal to 0.2112 .

\section{Conclusion}

Although the literature has addressed the relationship of investor protection resulted from country-level and firm-level governance standards, market disciplines resulted from firm-level accounting disclosure and innovations, relatively limited evidence of whether market disciplines and investor protection are substitutes or compliments in determining firms' innovation activities.

This paper explores how the relationship between accounting disclosure and innovation activities differ in different legal environments and firm-level corporate governance. To test our hypotheses, our firm-level accounting disclosure and corporate governance data is obtained from the survey data by Credit Lyonnais Securities Asia. We use the three country-level governance measures such as judicial efficiency, legality, and shareholder rights from La Porta et al. (1998) and the International Country Risk Guide (2000). We obtain our dependent variable from Worldscope, and define $R \& D$ as the ratio of a firm's $R \& D$ expenditures to sales. We also control for the logarithm of firm assets, total liability, accounting earnings, GDP growth, GDP per capita. Our sample period is between 2000 and 2005. Our final sample includes 807 observations in fourteen emerging markets.

Empirically, we use $\mathrm{R} \& \mathrm{D}$ as our innovation measure. The key independent variables are the interaction terms between firm-level accounting disclosure and governance variables. Specifically, we estimate the following equation:

Company-R\&D $=\alpha+\beta 1$ Accounting-Disclosure $+\beta 2$ Governance Variables $+\beta 3$ Accounting-Disclosure * Governance Variables $+\beta 4$ Control variables + Industry effects + Year effects $+\varepsilon$

Using the sample across 14 emerging markets, the paper reports that the effects of firm-level accounting disclosure on innovation activities are more important in a country with weaker 
governance standards and for firms with poor corporate governance. The results suggest that firm-level market disciplines can substitute for investor protection.

There are also policy implications in this research. The existing literature shows that innovation contributes to countries' economic growth (Aghion and Howitt, 2006) and firms are trying to promote innovation (Hoskisson et al., 2002). Thus, it is an important issue to increase a country's innovation activities for policy makers. To achieve that goal, it is better for them increase firms' accounting disclosure level and the effects are affected by firms' governance environment.

\section{References}

Aghion, P., \& Howitt, P. (2006). Appropriate growth policy: A unifying framework. Journal of the European Economic Association, 4, 269-314. http://dx.doi.org/10.1162/jeea.2006.4.2-3.269

Aghion, P., John, V. P., \& Zingales, L. (2013). Innovation and institutional ownership. American Economic Review, 103(1), 277-304. http://dx.doi.org/10.1257/aer.103.1.277

Berkowitz, D., Pistor, K., \& Richard, J. (2003). Economic development, legality, and the transplant effect. European Economic Review 47(1), 165-195. http://dx.doi.org/10.1016/S0014-2921(01)00196-9

Chen, V. Z., Li, J., \& Shapiro, D. M. (2011). Are OECD-prescribed "good corporate governance practices" really good in an emerging economy? Asia Pacific Journal of Management, 28(1), 115-138. http://dx.doi.org/10.1007/s10490-010-9206-8

Francis, B. B., Hasan, I., Huang, Y., \& Sharma, Z. (2012a). Do banks value innovation? Evidence from US Firms. Financial Management, Spring, 159-185. http://dx.doi.org/10.1111/j.1755-053X.2012.01181.x

Francis, B., Hasan, I. \& Song, L. (2012b). Are firm- and country-specific governance substitutes? Evidence from financial contracts in emerging markets. Journal of Financial Research, 35(3), 343-374. http://dx.doi.org/10.1111/j.1475-6803.2012.01320.x

Gibson, M. (2003). Is corporate governance ineffective in emerging markets? Journal of Financial and Quantitative Analysis, 38(1), 231-250. http://dx.doi.org/10.2307/4126771

Hasan, I., \& Song, L. (2014). Disclosure and bank loan contracting: Evidence from emerging markets. Asian Review of Accounting, 22(1), 2-19 http://dx.doi.org/10.1108/ARA-10-2013-0069

Hasan, I., Song, L., \& Raymar, S. (2014a). Effects of corporate and country governance on R\&D investment: Evidence from emerging markets. Singapore Economic Review, Forthcoming.

Hasan, I., Song, L., Zhan, M. S., Zhang P., \& Zhang Z. G. (2014b). Corporate disclosure and financing arrangements: Evidence from syndicated loans in emerging markets, Asian Review of Accounting Forthcoming.

Holmstrom, B. (1989). Agency costs and innovation. The Journal of Economic Behavior and 
Organization, 12, 305-327. http://dx.doi.org/10.2307/3069305

Hoskisson, R. E., Hitt, M. A., Johnson, R. A., \& Grossman, W. (2002). Conflicting voices: The effects of institutional ownership heterogeneity and internal governance on corporate innovation strategies. Academy of Management Journal, 45, 697-716. http://dx.doi.org/10.2307/3069305

International Country Risk Guide - 2000. PRS Group, Inc.

Jensen, M. C. \& Meckling, W. H. (1976). Theory of the firm: Managerial behavior, agency costs and ownership structure. Journal of Financial Economics, 3(4), 306-360. http://dx.doi.org/10.1016/0304-405X(76)90026-X

Klapper, L. F. \& Love, I. (2004). Corporate governance, investor protection, and performance in emerging markets. Journal of Corporate Finance, 10(5), 703-728. http://dx.doi.org/10.1016/S0929-1199 (03)00046-4

La Porta, R., Lopez-de-Silanes, F., Shleifer, A., \& Vishny, R. W. (1998). Law and finance. Journal of Political Economy, 106(6), 1113-1155. http://dx.doi.org/10.1086/250042

O'Connor, M. and Rafferty, M. (2012). Corporate governance and innovation. Journal of Financial and Quantitative Analysis, 47(2), 397-41. http://dx.doi.org/10.1017/S002210901200004X

\section{Copyright Disclaimer}

Copyright for this article is retained by the author(s), with first publication rights granted to the journal.

This is an open-access article distributed under the terms and conditions of the Creative Commons Attribution license (http://creativecommons.org/licenses/by/3.0/). 